\title{
Endovascular aortic graft infection resulting in retroperitoneal abscess: report of a case
}

Enrico Ferri, Laura Magrini, Marco Alfano, Michela Del Parco, Chiara Serena Gori, Salvatore Di Somma

Department of Emergency Medicine, AO Sant'Andrea, La Sapienza University of Rome, Rome, Italy

\section{SINTESI}

Linfezione è una rara complicazione delle procedure endovascolari a livello aorto iliaco con una incidenza inferiore allo $0.5 \%$ e può determinare la comparsa di un ascesso retroperitoneale evolvente verso la sepsi e il sanguinamento gastrointestinale. In più del $50 \%$ dei casi le infezioni delle protesi endovascolari in sede aorto iliaca si manifestano a distanza di mesi o anni dalla procedura. In considerazione della recente applicazione e della progressiva diffusione delle procedure endovascolari, è pre- vedibile un crescente aumento delle complicanze settiche post-procedurali che potrebbero rappresentare un problema emergente per il medico d'urgenza.

Il mantenimento di un alto indice di sospetto in presenza di un paziente portatore di protesi endovascolare aorto iliaca, con febbre prolungata o ricorrente elo dolore addominale elo dolore lombare, la richiesta precoce di una TC addome potrebbe migliorare la "performance" diagnostico terapeutica nel Dipartimento di Emergenza.

\section{Introduction}

Endovascular prosthetic grafts may be related to several complication including endoleak, device migration, restenosis, thrombosis, rupture and infection $^{1-3}$. Infection is, to date, a rare complication of endovascular procedures, with an incidence inferior to $0.5 \%$ but potentially catastrophic ${ }^{4}$.

When an endograft in the aortoiliac position is involved it may result, as in open surgery implanted, in a retroperitoneal abscess and aortoenteric fistulation potentially evolving to sepsis, gastrointestinal bleeding, septic or hemorragic shock ${ }^{2-7}$.

The low rate of occurrence and awareness with the relatively aspecific clinical presentation and progressive evolution seem to cause a considerably delay in diagnosis and a poor outcome $e^{2,3}$.

\section{Case report}

A 83 years old man with diabetes mellitus, hypertension and benign prostatic hypertrophy presented to the Emergency Department (ED) refer-

ring a one month history of low grade fever, back discomfort and dysuria associated with a subcutaneous mass in the inferior right dorsum arising from few days. The patient underwent endovascular treatment for an abdominal aortic aneurysm 12 months before and was on treatment with insulin, ramipril, aspirin and thamsulosin.

He did not show any peri- or post-surgical complication.

General physician visited the patient eight days before the mass appearance and suspected an urinary tract infection.

The patient underwent empiric antibiotic therapy with quinolones (ciprofloxacin $500 \mathrm{mg}$ bid) for 5 days without any benefit. After performed an urine colture and waiting for the results, the antibiotic switched to a beta lattamase inibhitor penicillin (amoxicillin/clavulanate $1 \mathrm{~g}$ bid).

At time of ED admission clinical examination detected hypotension (blood pressure 95/60 $\mathrm{mmHg}$ ), tachycardia (heart rate 120), dehydration, a low grade dolorability in the right abdomen with- 

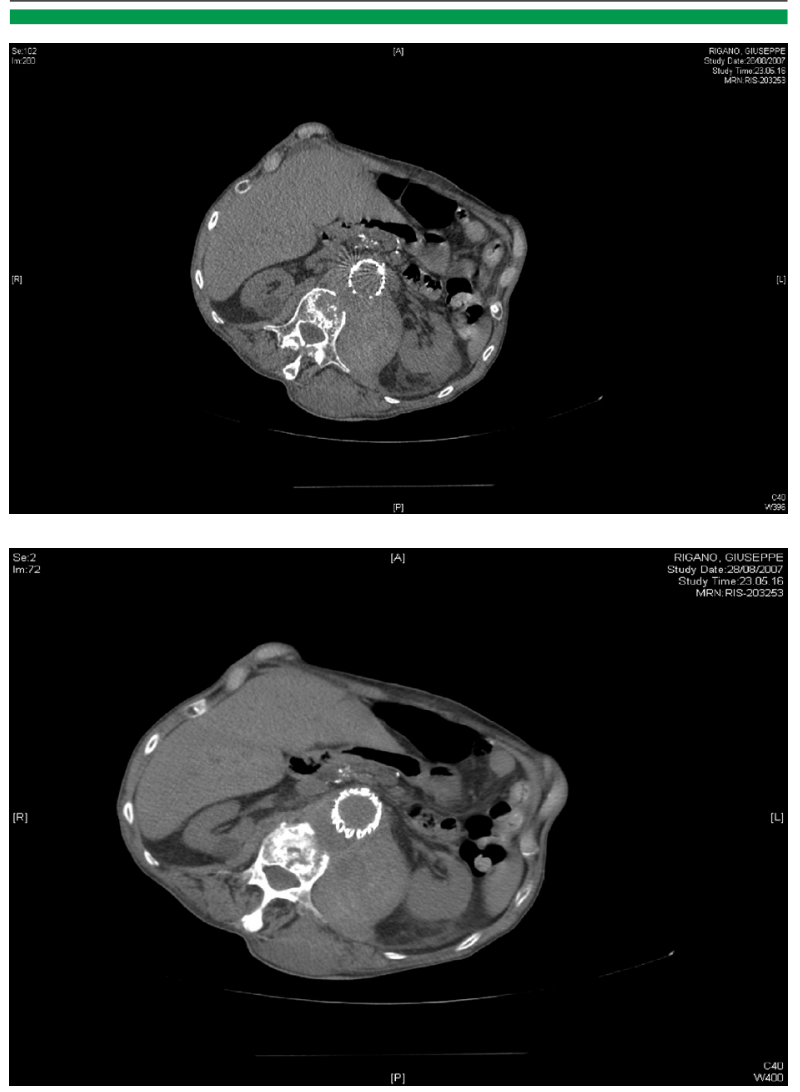

Fig. 1 - An unhenanced thoraco abdominal CT identified a periaortic retroperitoneal abscess with pleural and subcutaneos fistulation (arrows).

out peritonism signs and an ovalar subcutaneous soft mass in the inferior right dorsum. Fever was $38.5^{\circ} \mathrm{C}$. Laboratory revealed anemia (haemoglobin $6.5 \mathrm{~g} / \mathrm{dl}$ ), leucocytosis (white blood cells 18.600/ $\mathrm{ul})$, increased c reactive protein $(25.2 \mathrm{mg} / \mathrm{dl})$, creatinine $(2.6 \mathrm{mg} / \mathrm{dl})$ and blood urea $(56 \mathrm{mg} / \mathrm{dl})$. Urine dipstick was positive for haematuria and leucocyturia. An urgent ultrasonography demonstrated a subcutaneous fluid mass communicating with the pleural space.

This prompted an unhenanced thoraco abdominal CT which identified a periaortic retroperitoneal abscess with pleural and subcutaneos fistulation (Figure 1).

A vascular surgical consultation has been performed but the patient deceased for septic shock two hours after the ED admission, and before any surgical procedure.

\section{Discussion}

Infectious complications are rare after endovascular procedures and include septic embolization, periarterial and retroperitoneal abscess, sepsis and aortoenteric or inguinal fistulation ${ }^{2-7}$.

These may occur early in the post surgical period but in more than $50 \%$ of cases months or years after the procedure ${ }^{3}$, recently Heyer et al. showed that the mean time from the index procedure to the diagnosis of infection was 243.6 days $+/-74.5^{6}$. Once placed, the metallic stent is gradually and completely covered by endothelium in 4 weeks but the stented area may be more prone than native artery in capturing circulating bacteria ${ }^{3}$.

Infection may arise from bacteria introduced at the time of angioplasty or stent placement by a failed steril technique or by germs present in the plaque ${ }^{3}$. Neverthless, in completely endothelium covered stent, any intervention next to the stented area could damage the endothelium determining an infection ${ }^{3,5}$.

Coexisting neoplastic and immune disorders, inflammatory bowel disease, concomitant adjunctive procedures and treatment of false aneurysm apparently seem to determinate an higher risk of bacterial arterial wall colonization ${ }^{3,5}$.

Other risk factors for infection are the prolonged use of an indwelling catheter as in thrombolytic therapy, an hematoma formation and the re-use of the same artery for vascular access in a week ${ }^{2,3}$. It remains an uncommon occurrence and most cases have been described in single case reports ${ }^{1-7}$.

In the aortoiliac site the frequency of endovascular stent graft infection is $<0.5 \%{ }^{2,4}$.

However, as the growing number of endovascular procedures, and as the actually midterm follow up in most cases, septic sequelae will no doubt continue to occur with increased frequency and may represent an emerging problem in the ED for the emergency physician, because of his low familiarity with this patologic condition, of an increasing follow up lenghtiness, and because of potentially catastrophic complications and high mortality of this condition ${ }^{2-5}$.

Endovascular graft infection begins with aspecific clinical manifestations, including fever, weakness, malaise, weight loss, abdominal, back, and leg pain, claudication, anemia, intestinal bleeding and elevated biochemical and inflammatory mark$\operatorname{ers}^{1-3,6}$. But the evolution may be progressive to sepsis and to multiorgan failure syndrome or hemorragic shock ${ }^{2-5}$.

CT scan is the imaging technique that produces the most reliable and rapid diagnosis ${ }^{1-3}$.

A periprosthetic infection should be searched and excluded in any patient with an aortic stent graft 
presenting prolonged or recurrent fever and or abdominal, back or flank pain.

An high index of suspicion and a low threshold for obtaining CT scan should increase the clinician's ability to make a timely diagnosis in the ED setting.

\section{References}

1. Buth J, Laheij RJF. On behalf of the EUROSTAR Collaborators Early complications and endoleaks after endovascular abdominal aortic aneurysm repair; report of a multicentric study. J Vasc Surg 2000; 31(1 Pt 1): 134-146.

2. Ducasse E, Calisti A, Speziale F et al. Aortoiliac stent graft infec- tion: current problems and management. Ann Vasc Surg 2004; 18: 521-526.

3. Fiorani P, Speziale F, Calisti A et al. Endovascular graft infection: preliminary results of an international enquiry. J Endovasc Ther 2003; 10: 919-927.

4. Starr J, Walker G, Vaccaro P. Endograft infection presenting as a ruptured aortic aneurysm. Ann Vasc Surg 2009; 23 (6): 787.e7-9.

5. Sharif MA, Lee B, Lau LL et al. Prosthetic stent graft infection after endovascular abdominal aortic aneurysm repair. J Vasc Surg 2007; 46: 442-448.

6. Heyer KS, Modi P, Morasch MD et al. Secondary infections of thoracic and abdominal aortic endografts. J Vasc Interv Radiol 2009; 20(2): 173-179. Epub 2008 Dec 20.

7. Chenu C, Marcheix B, Barcelo C, Rousseau H.. Aorto-enteric fistula after endovascular abdominal aortic aneurysm repair: case report and review. Eur J Vasc Endovasc Surg 2009; 37(4): 401-406. Epub 2009 Feb 10.

\section{ABSTRACT}

Infection is a rare complication of aortoiliac endovascular procedures, with an incidence inferior to $0.5 \%$, and it may result in a retroperitoneal abscess potentially evolving to sepsis and gastrointestinal bleeding.

In more than $50 \%$ of cases endovascular aortoiliac prosthetic grafts infection occur months or years after the procedure.

The growing number of endovascular procedures, and as the actually midterm follow up in most cases, septic sequelae will no doubt continue to occur with increased frequency and may represent an emerging problem in the ED for the emergency physician.

Endovascular graft infection begins with unspecific clinical manifestations. An high index of suspicion in any patient with an aortic stent graft presenting prolonged or recurrent fever and or abdominal or back pain and a low threshold for obtaining CT scan should increase the clinician's ability to make a timely diagnosis in the ED setting. 